\title{
ENTREVISTA COM A TRADUTORA LEIKO GOTODA
}

Além de ter feito traduçôes de obras de Eiji Yoshikawa, Haruki Murakami, Yukio Mishima e Kenzaburo Oê, Leiko Gotoda traduziu também vários livros de Junichiro Tanizaki: Diário de um velho louco (2002) e As irmás Makioka (2007), publicados pela Estação Liberdade, e Voragem (2001), Há quem prefira urtigas (2003) e Em louvor da sombra (2007), publicados pela Companhia das Letras. Nesta entrevista, realizada no dia 06 de junho de 2013 em São Paulo por Olga Kempinska, Leiko Gotoda conta sobre sua formação como tradutora, sobre os maiores desafios da tradução do japonês para o português e recorda também algumas anedotas sobre seu tio Tanizaki.

A formação do tradutor raramente segue uma linha clara e diretamente traçada. Como se deu sua escolha por essa profissáo e qual foi o início do seu rico percurso como tradutora literária do japonês?

Sempre gostei muito de ler e de escrever. Desde a infância costumava ler livros em japonês, dados por minha mãe. Posteriormente, comecei a gostar também da leitura em português. Formei-me em magistério e nessa fase comecei também a estudar inglês e a ler livros nessa língua. Em seguida, casei-me, trabalhei um pouco, mas aí vieram quatro filhos, um atrás do outro. Não havia tempo para mais nada, eu me dediquei completamente à criação dos filhos. Quando minha caçula foi para a faculdade, eu me vi perdida, sem ter muito com o que me ocupar e resolvi retomar então tudo aquilo que tinha interrompido. Voltei a pensar em mim, retomei a ideia de uma profissão para mim. Uma amiga minha, que se havia formado como tradutora do inglês para o português, perguntou-me: "Leiko, por que você não faz também? Você gosta tanto de ler e de escrever!”. Achei maravilhosa a ideia e matriculei-me em um curso de formação de tradutores do inglês. Ocupei-me durante um tempo com tradução técnica, mas era à tradução literária que desejava mesmo me dedicar. Traduzi então 
alguns livros do inglês para o português, mas não estava muito satisfeita e um dia me vi pensando: "Mas por que estou fazendo isso, se conheço tão bem o japonês? - se fui criada na língua japonesa?”. Houve também um belo aprofundamento na cultura japonesa graças a meu marido, que é japonês. Pensei então: "Por que não traduzo do japonês?". Fiquei na dúvida se a minha formação, voltada para o inglês, me qualificaria para traduzir do japonês, mas descobri que, na verdade, a formação do tradutor envolve três elementos fundamentais: o conhecimento da língua da qual se traduz, o conhecimento da cultura dessa língua e um conhecimento melhor ainda da língua para a qual se traduz. Comecei a pensar então sobre o livro que traduziria do japonês e cheguei à conclusão de que tinha que traduzir o Musashi de Eiji Yoshikawa, a famosa saga, que acabou sendo publicada pela Estação da Liberdade. Na verdade, foi uma grande surpresa no início, porque o trabalho se revelou muito mais difícil do que pensei que fosse e levei realmente muito tempo para traduzir aquele livro muito grosso. Mas finalmente consegui e foi assim que começou meu trabalho como tradutora literária do japonês para o português.

Então, há na verdade três línguas envolvidas na sua formação: o japonês, $o$ inglês e o português. $E$ a própria chegada até o japonês parece ter-se dado através de uma língua estrangeira, o inglês...

Exatamente. E também, na época em que comecei a traduzir o Musashi, ainda não havia bons dicionários do japonês para o português. Então eu frequentemente triangulava, traduzindo do japonês para o inglês e do inglês para o português. Foi um processo extremamente trabalhoso, mas também muito gratificante. Gostei tanto de ver que aquela língua e aquela cultura, que eu achava quase impossível de serem transpostas para o português, de repente se transformavam em um livro, em uma história.

O português e o japonês são línguas extremamente diferentes, tanto na escrita quanto na construção linguística e no uso discursivo. Quais são os maiores desafios para o tradutor do japonês?

O maior desafio na tradução do japonês para o português é, ainda, a cultura. O conhecimento da cultura japonesa é essencial, pois, sem esse con- 
hecimento, acaba-se traduzindo de uma maneira errada, ou dando uma nuance completamente errada. Como disse Paulo Rónai: ou você traduz ao pé da letra, trazendo, de uma forma um tanto assustadora, todas as extravagâncias do autor para o leitor, ou, ao contrário, você tenta levar o leitor para a terra do autor. Mas, nesse segundo caso, você corre um risco considerável de aplainar e neutralizar coisas que são extremamente diferentes. As estruturas arquitetônicas japonesas, por exemplo, são totalmente diferentes das brasileiras. E assim, uma palavra aparentemente simples, como um "corredor", que em japonês se chama rôka, revela-se muito problemática na tradução. No Brasil e no Ocidente, quando se diz "corredor", imagina-se uma passagem que liga dois extremos, com portas dos dois lados. Quando em um livro japonês aparece a palavra "rôka", ela pode remeter também a esse sentido, sobretudo quando a história transcorre em um ambiente moderno. No entanto, quando o "rôka" se refere especificamente à arquitetura japonesa tradicional, trata-se de uma passagem, que, sem dúvida, interliga os quartos, mas que não é fechada com duas paredes. Pois o rôka rodeia toda a casa, mas abre-se também para um jardim. Então, quando o texto diz que um samurai perseguido caiu do rôka, não convém traduzir "rôka" como "corredor". Não é possível cair de um corredor! (risos). O tradutor precisa então buscar uma outra solução: o "avarandado", por exemplo, mas que tampouco corresponde exatamente ao rôka, por não ser realmente uma passagem... Ao lado do vocabulário japonês relacionado com a arquitetura, aquele que descreve o vestuário é um outro grande desafio. O obi, aquela faixa que prende o kimono é, por exemplo, um elemento muito importante na cena inicial das Irmás Makioka de Tanizaki, na qual as moças se arrumam para sair. Nessa deliciosa cena, a narrativa diz que quando a mulher respirava, o obi rangia. Tanizaki escreveu literalmente que o obi fazia "quiu quiu"... (risos). Como trazer para o português essa onomatopeia, da qual, no entanto, depende todo o sabor da cena?

Em japonês, as formas linguísticas utilizadas pelas mulheres são bastante diferentes das formas utilizadas pelos homens, e essa diferença parece ser dificilmente transponível na tradução para o português. É de todo possível transpor essa diferença de gênero? 
Quase impossível. Eu não poupei esforços para sugeri-la. Hoje em dia, existem em japonês as linguagens específicas da mulher e do homem, além da linguagem respeitosa. No uso dos pronomes pessoais, por exemplo, não convém traduzir todas essas diferenças pela mera diferença entre "você" e "senhor". Perante essa dificuldade, optei por um acréscimo da gradação mais antiga e regional, "vós" e "tu” e, assim, consegui transmitir uma vaga ideia do que seria a diferença genérica que existe em japonês.

Além dos romances, a senhora traduziu também o famoso ensaio de Tanizaki intitulado Em louvor da sombra, no qual o escritor compara a estética oriental e a estética ocidental, usando como exemplos os espaços das casas, dos banheiros, dos utensílios, do tipo de maquiagem e das formas da iluminação dos interiores. Em geral, a diferença cultural parece ser um elemento muito importante na obra de Tanizaki, que experimentou uma intensa fascinação pelo Ocidente. Ele viajou alguma vez para fora do Japão, para algum país ocidental?

Não, nunca. Ele tinha medo de viajar de avião. Até no momento da recepção de um importante prêmio americano, o escritor recusou-se a buscá-lo fora do país. Tanizaki nunca saiu do Japão. Mas é verdade que em sua obra existem muitas referências àquele embate que se deu no Japão depois da abertura Meiji, da abertura geral dos portos, pela qual a cultura ocidental penetrou de repente no Japão. A violência que resultava da assimilaçáo vertiginosa da cultura ocidental pelos japoneses impressionou muito Tanizaki. Mas, além do fascínio pelo Ocidente, há também em sua obra um profundo amor pela tradição própria: a melhor prova dessa atitude afirmativa é sua tradução para o japonês moderno do antigo romance Genji Monogatari de Murasaki Shikibu. Uma transformação importante que se deu na vida e na obra de Tanizaki decorre na verdade da mudança de foco entre duas regióes japonesas: a passagem da preferência pela modernidade do Kanto, com sua capital febril, Tóquio, para o gosto pela região mais tradicional chamada Kansai. Com o passar do tempo, Tanizaki descobriu que aquela região de Osaka e de Kyoto, impregnada pelo passado, era muito fascinante: uma comida deliciosa, por exemplo, não tão salgada quanto a de Tóquio, o teatro de bonecos, o dialeto de Osaka, 
que o escritor tentou introduzir em seus textos. E o romance As Irmãs Makioka centra-se sobretudo nas mulheres de Kansai, irresistivelmente indecisas e hesitantes e tão diferentes das mulheres seguras e secas de Tóquio.

As mulheres ocupam um lugar muito importante na obra de Tanizaki...

Ah, sim! As mulheres são muito importantes para ele. Alguns biógrafos interpretam essa fascinação por meio da relação edipiana com a mãe, a qual Tanizaki achava maravilhosa. De fato, em sua obra, com a imagem da mulher surge também frequentemente a imagem do belo.

Mas não surge também uma ideia de um perigo, sobretudo nas numerosas representaçóes de mulheres japonesas ocidentalizadas, aquelas que rejeitam os gostos tradicionais? Existe, por exemplo, uma pequena narrativa sobre uma gata, um homem e duas mulheres, na qual é a gata Lily, de raça e nome ocidentais, que, de uma forma um pouco cômica, monopoliza o afeto de todas as personagens do triângulo amoroso.

(Risos) Ah, sim! É o Neko to Schôzo to futari no onna, adoro esse livro. E, além das mulheres, Tanizaki gostava demais dos gatos! Minha mãe me contava que ele tinha uma gata chamada Tama. E ele chamava essa gata de uma forma respeitosa: "O Tama-san". E a Tama era a rainha do pedaço.

Koisan, suzuri, sumi, tatami, sensei, miai... Nos textos traduzidos do japonês, surgem muitos estrangeirismos, que às vezes são destacados em itálico, às vezes vêm até acompanhados de notas. Gostei particularmente da nota explicativa que acompanha a palavra "sensei", no início do romance Voragem, e que diz que "sensei" significa literalmente "aquele que nasceu primeiro", para justificar a legitimidade da atividade orientadora. E, de fato, a ideia de ter nascido antes não existe nem na palavra "mestre", nem na palavra "mentor"... O que, em geral, motiva o tradutor a se servir dos estrangeirismos, a renunciar à domesticação?

É aquela dificuldade que lhe expliquei no início: algumas diferenças culturais resistem à transposição. O "tatami”, por exemplo: como transpor 
essa palavra em português? Uma peça retangular de uma fibra vegetal tecida, que é destacável e que, ao mesmo tempo, serve de unidade de medida de aposentos. Náo tendo como transpor toda essa abrangência do sentido, preferi deixar "tatami", no começo até com uma nota explicativa. Com o tempo, passei a abandonar a nota, porque pensei que os leitores já sabiam de que se tratava, graças, por exemplo, à popularidade do judô, no qual os oponentes lutam sobre o tatami.

E a ambiguidade do sentido das palavras, tão frequentemente citada pelos tradutores como uma fonte inesgotável de dificuldades? Ela se deixa sentir muito na traduçáo do japonês? Pergunto porque, na nota que acompanha a traduçáo do ensaio Em louvor da sombra, a senhora comenta algumas das dificuldades envolvidas na traduçáo da palavra "furyu" e sua decisáo de transpô-la de uma maneira dupla, ora como "elegância", ora como "estesia".

A ambiguidade cria, de fato, uma dificuldade enorme. E às vezes realmente não há como persistir em ser consequente e traduzir a palavra sempre da mesma maneira. É preciso antes de mais nada saber seguir as nuanças. Agora, por exemplo, estou traduzindo um romance de Abe Kobo, no qual aparece frequentemente a palavra "hyôjô", que significa "expressão", no sentido muito amplo e variado: expressão do rosto, expressão literária. Mas, de repente, essa palavra significa também em japonês "a fisionomia da pessoa", que remete a um fenômeno muito mais permanente do que uma mera expressão passageira. Revela-se então necessário encontrar flexibilidade e criatividade para se fazer uma boa escolha. A palavra " $f u$ ryu", que comentei naquela nota do ensaio de Tanizaki, significa, de fato, tanto "elegância", quanto "refinamento", "bom gosto" e até "estesia”, e é, às vezes, muito difícil decidir qual dessas palavras será a mais adequada.

Tanto mais que essa palavra "furyu" é utilizada por Tanizaki também no contexto de uma reflexáo sobre as experiências no banheiro... Ele parece ter tido um senso de humor bastante especial...

Muito especial mesmo! (risos) Minha mãe tinha o mesmo tipo de humor e fazia, às vezes, observaçóes que me deixavam completamente sem jeito. 
No recente romance de Bernardo Carvalho $O$ sol se póe em São Paulo, amplamente inspirado na trama de Voragem de Tanizaki, o narrador menciona a presença no Brasil de uma sobrinha de Tanizaki. Afirma até ter conversado com ela. A senhora é realmente sobrinha do escritor japonês? Já o encontrou alguma vez pessoalmente?

Bernardo Carvalho esteve aqui em casa! Ele veio conversar comigo na época da escrita daquele romance... Nunca encontrei Tanizaki pessoalmente. Ele faleceu quando eu tinha 20 poucos anos e tinha acabado de me casar. Mas a minha mãe havia ido ao Japão e havia se encontrado com ele. Ela mantinha com ele também uma correspondência.

O romance de Carvalho é fascinante, sobretudo por tratar da questão da emigração e da relaçáo entre os descendentes dos emigrantes japoneses e a cultura de origem de seus antepassados. E a sua mãe, ela contava algumas anedotas sobre Tanizaki?

Ela contava muitas. Dizia, por exemplo, que meu tio era muito guloso. E bastante ranzinza também. E que adorava os gatos. O mais velho dos irmãos, Tanizaki parece ter sido também muito amoroso com o resto da família, na qual se notam aliás, costumes bastante especiais. $\mathrm{O}$ avô da minha mãe e de Tanizaki, que trabalhava com a produção de vinhos, detestava as guerras e era um homem pacifista em um Japão militarista e muito guerreiro. Era também católico em um país xintoísta e budista. Além disso, simpatizava com as mulheres e respeitava-as mais do que era o costume e, tendo diversos filhos, homens e mulheres, os homens ele "deu", para que assumissem o nome de outras famílias, e as mulheres ele conservou, dando-lhes o nome da família. Dessa maneira, as mulheres da família não eram "dadas" em casamento: eram, antes, os maridos que vinham "dados" a elas. Assim, contra os hábitos correntes, foram também as mulheres que continuaram a carregar o nome Tanizaki, que é agora conhecido como o nome do escritor traduzido no mundo inteiro.

Recebido em: 05/08/2013 Aprovado em: 10/09/2013 